\title{
The growing spectrum of antibody-associated inflammatory brain diseases in children
}

\section{OPEN}

Sandra Bigi, MD, MSc*

Manisha Hladio, BSc, MSc*

Marinka Twilt, MD, MSc, PhD

Josep Dalmau, MD, PhD

Susanne M. Benseler, $\mathrm{MD}, \mathrm{MSc}, \mathrm{PhD}$

Correspondence to Dr. Bigi: sandra.bigi@insel.ch

Supplemental data at Neurology.org/nn

\section{ABSTRACT}

Objective: To describe the clinical spectrum, diagnostic evaluation, current management, and neurologic outcome of pediatric antibody-associated inflammatory brain diseases (AB-associated IBrainD).

Methods: We performed a single-center retrospective cohort study of consecutive patients aged $\leq 18$ years diagnosed with an AB-associated IBrainD at The Hospital for Sick Children, Toronto, Ontario, Canada, between January 2005 and June 2013. Standardized clinical data, laboratory test results, neuroimaging features, and treatment regimens were captured.

Results: Of 169 children (93 female, 55\%) diagnosed with an IBrainD, 16 (10\%) had an ABassociated IBrainD. Median age at presentation was 13.3 years (range 3.1-17.9); 11 (69\%) were female. Nine patients (56\%) had anti-NMDA receptor encephalitis, 4 (25\%) had aquaporin-4 autoimmunity, 2 (13\%) had Hashimoto encephalitis, and 1 (6\%) had anti-glutamic acid decarboxylase 65 (GAD65) encephalitis. The key presenting features in children with antiNMDA receptor encephalitis, Hashimoto encephalopathy, and anti-GAD65 encephalitis included encephalopathy, behavioral symptoms, and seizures; patients with aquaporin-4 autoimmunity showed characteristic focal neurologic deficits. Six patients (38\%) required intensive care unit admission at presentation. Median time from symptom onset to diagnosis was 55 days (range 6-358). All but 1 patient received immunosuppressive therapy. One child with anti-NMDA receptor encephalitis died due to multiorgan failure. At last follow-up, after a median follow-up time of 1.7 years (range $0.8-3.7$ ), 27\% of the children had function-limiting neurologic sequelae.

Conclusions: Children with AB-associated IBrainD represent an increasing subgroup among IBrainD; 1 in 4 children has function-limiting residual neurologic deficits. Awareness of the different clinical patterns is important in order to facilitate timely diagnosis and initiate immunosuppressive treatment. Neurol Neuroimmunol Neuroinflamm 2015;2:e92; doi: 10.1212/ NXI.0000000000000092

\section{GLOSSARY}

AB-associated IBrainD = antibody-associated inflammatory brain diseases; $\mathbf{A Q P 4}=$ aquaporin-4; $\mathbf{C R P}=\mathrm{C}$-reactive protein; ESR = erythrocyte sedimentation rate; FLAIR = fluid-attenuated inversion recovery; GAD65 = glutamic acid decarboxylase 65; IBrainD = inflammatory brain diseases; ICU = intensive care unit; IgG = immunoglobulin G; LETM = longitudinally extensive transverse myelitis; $\mathbf{N M O}=$ neuromyelitis optica; $\mathbf{O N}=$ optic neuritis; PSOM = Pediatric Stroke Outcome Measure; TPO = thyroperoxidase.

Inflammatory brain diseases (IBrainD) affect previously healthy children and can cause lifethreatening neurologic deficits. The disease spectrum encompasses several distinct entities, including vasculitides, granulomatous conditions, and $\mathrm{T}$ cell- and antibody-associated diseases. ${ }^{1-5}$ In antibody-associated inflammatory brain diseases (AB-associated IBrainD), activated

\footnotetext{
*These authors contributed equally to the manuscript.

From the Department of Pediatrics (S.B.), Division of Neurology; Department of Pediatrics (M.H.), Division of Rheumatology; and Department of Emergency Medicine and Research Institute (S.M.B.), The Hospital for Sick Children, University of Toronto, Ontario, Canada; Department of Pediatrics (S.B.), Division of Child Neurology, University Children's Hospital, Berne, Switzerland; Department of Pediatric Rheumatology (M.T.), Aarhus University Hospital, Aarhus, Denmark; Catalan Institution of Research and Advanced Studies (ICREA) and Biomedical Research Institute August Pi i Sunyer (IDIBAPS) (J.D.), Hospital Clinic, University of Barcelona, Spain; Department of Neurology (J.D.), University of Pennsylvania, Philadelphia; and Section of Rheumatology (S.M.B.), Department of Pediatrics, Alberta Children's Hospital, University of Calgary, Alberta, Canada. Funding information and disclosures are provided at the end of the article. Go to Neurology.org/nn for full disclosure forms. The Article Processing Charge was paid by the authors.

This is an open access article distributed under the terms of the Creative Commons Attribution-Noncommercial No Derivative 3.0 License, which permits downloading and sharing the work provided it is properly cited. The work cannot be changed in any way or used commercially.
} 
B cells produce specific antibodies against different structures in the CNS, including cell surfaces, synaptic proteins, and channels. ${ }^{3,6-9}$ Despite the growing number of recognized conditions and the achievements related to targeted treatment, the clinical heterogeneity within this group often leads to a delay in diagnosis and hence a high risk of poor outcomes.

Therefore, the objectives of this study were to (1) describe the clinical phenotype of distinct childhood AB-associated IBrainD, (2) review the diagnostic evaluation and current management, and (3) assess the neurologic outcome at the last follow-up.

METHODS Population and setting. This was a singlecenter retrospective cohort study of consecutive patients younger than 18 years of age who were seen at The Hospital for Sick Children from January 1, 2005 to June 30, 2013, and diagnosed with an IBrainD. Included were patients with a confirmatory antibody detected in serum and/or CSF (see testing panel later in this section) in the context of a newly acquired neurologic and/or psychiatric deficit not otherwise explained with a follow-up period of at least 6 months. ${ }^{10}$ Excluded were children with non-AB-associated IBrainD or with IBrainD that were presumed to be $A B$-associated but with no confirmatory test. All children diagnosed with IBrainD were followed in the IBrainD and CNS vasculitis clinics at The Hospital for Sick Children. Standardized clinical data, laboratory test results, neuroimaging features, and outcome information were prospectively collected and captured in a designated research database (BrainWorks, the international Web-based passwordprotected prospective cohort of children with IBrainD). Patients were identified from the database and data were supplemented with additional information found in the electronic patient charts.

Standard protocol approvals, registrations, and patient consents. Written informed consent was obtained from all study participants (parents/legal guardians). The study was approved by the research ethics board of The Hospital for Sick Children (REB 1000014279).

Clinical data. Information of interest included sex, age at diagnosis, duration of symptoms before diagnosis, initial clinical presentation (mental status, level of consciousness, neurologic examination, seizures), severity of disease at presentation (ward vs intensive care unit $[\mathrm{ICU}]$ admission), and length of acute inpatient management (defined as the length of time between initial presentation and discharge from acute care facility). The detailed definition of clinical signs and symptoms is given in table e- 1 at Neurology.org/nn.

Investigations. All study participants underwent a standardized test battery unless there were contraindications for certain tests to be performed. The general laboratory workup included white blood cell count, C-reactive protein (CRP), erythrocyte sedimentation rate (ESR), albumin, immunoglobulin $\mathrm{G}(\mathrm{IgG})$, von Willebrand factor antigen, protein $\mathrm{C} / \mathrm{S}$, factor $\mathrm{V}$ Leiden, homocysteine, lupus anticoagulants, methylenetetrahydrofolate reductase, C3, C4, ferritin, lipid profile, antinuclear antibodies, double-stranded DNA, anti-neutrophil cytoplasmic autoantibody, rheumatoid factor, anti-cardiolipin antibodies, anti-Ro antibodies, anti-La antibodies, thyroperoxidase (TPO) antibodies, and CSF analysis (cell count, protein, oligoclonal bands). Serologies included varicella-zoster virus, hepatitis B and C, enterovirus, Mycoplasma pneumoniae, cytomegalovirus, Epstein-Barr virus, Bartonella henselae, Treponema pallidum, and Borrelia burgdorferi.

A malignancy workup (abdominal ultrasound and/or MRI) was performed if indicated.

Antibody testing was performed prior to treatment initiation in all patients. Paired serum/CSF samples were used for antiNMDA receptor and anti-glutamic acid decarboxylase 65 (GAD65) antibody testing, as previously described. ${ }^{11}$ Testing included other cell surface or synaptic receptors (AMPA receptor, $\mathrm{GABA}_{\mathrm{A}}$ receptor, $\mathrm{GABA}_{\mathrm{B}}$ receptor, GlyR, mGluR5R, LGI1, Caspr2, DPPX). Anti-TPO antibodies were tested in serum at The Hospital for Sick Children; a titer of $>35$ IU/L was considered positive. Neuromyelitis optica (NMO)-IgG was tested in serum and/or CSF using ELISA. All NMO-IgG testing was performed at the same institution (NMO testing reference center).

MRI of the brain and/or spine at presentation was reviewed by 2 independent investigators (S.B., S.M.B.). Lesion location (supratentorial/infratentorial/spinal cord) and enhancement were recorded. Spinal cord lesions of $\geq 3$ segments were identified as longitudinally extensive transverse myelitis (LETM).

Immunosuppressive treatment included the institutional protocol (see figures e-1 and e-2, depending on disease severity at onset) or modified regimens. Symptomatic treatment included management of seizure control and psychotropic agents as indicated.

Outcome. Primary outcome was the neurologic functioning at last clinical encounter, defined by the Pediatric Stroke Outcome Measure (PSOM). The PSOM is a standardized and validated pediatric outcome measure routinely used in BrainWorks and in the IBrainD clinics. The PSOM categorizes outcome as either good (normal function or mild deficit with no impact on function) or bad (any deficit affecting function). ${ }^{12}$

Secondary outcomes included survival, school participation, support at school (defined as presence of an individualized education program or other support), and assessment of residual seizures.

Analysis. Children were assigned to distinct subgroups based on their presenting antibody. For each subgroup, clinical presentation, inflammatory markers, neuroimaging findings, and outcome measures were captured using descriptive statistics.

RESULTS A total of 169 children were diagnosed with an IBrainD. Sex distribution was balanced (93 female, 55\%); the mean age at diagnosis was 9.9 years (SD 4.8 years). Figure 1 illustrates the distribution of the different diagnoses encountered in this cohort. The largest group was formed by patients with primary $(\mathrm{n}=67 ; 40 \%)$ and secondary $(\mathrm{n}=18 ; 10 \%)$ vasculitis and CNS vasculopathies $(n=24 ; 14 \%)$, presenting respectively with acute ischemic stroke or nonischemic focal neurologic deficits alongside an abnormal brain MRI in the majority of the cases. The group of other IBrainD ( $\mathrm{n}=44 ; 26 \%)$ is heterogeneous, including patients with Rasmussen encephalitis or granulomatous diseases presenting with focal seizures/epilepsia partialis continua and cranial neuropathies with or without raised intracranial pressure, respectively. A total of 16 children $(10 \%)$ were identified as having an $\mathrm{AB}$-associated 
Figure 1 Frequency of pediatric inflammatory brain diseases (IBrainD) by diagnosis

Total number of children diagnosed with an IBrainD $n=169$

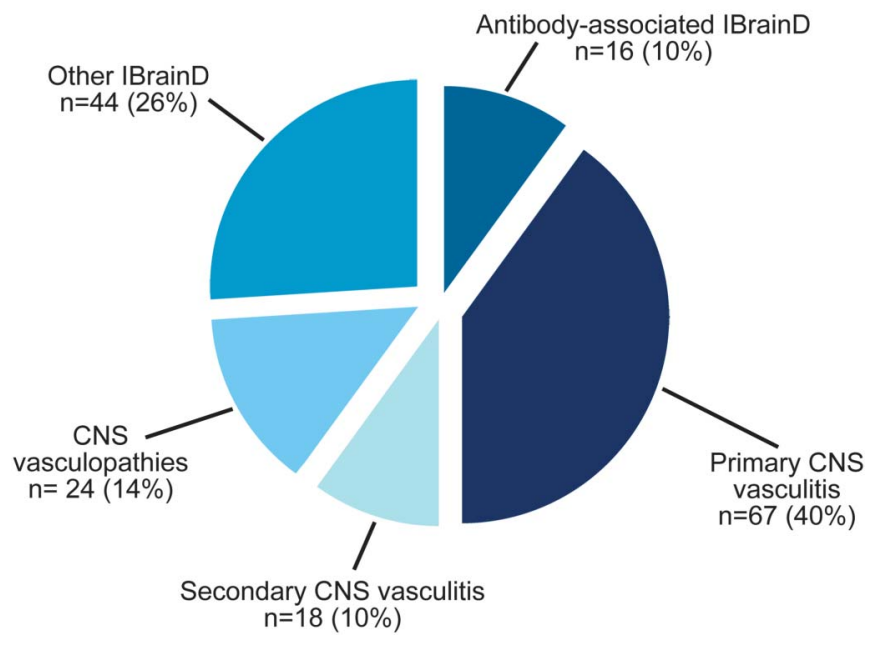

IBrainD; an outline of their baseline characteristics is given in table 1. Children with $\mathrm{AB}$-associated IBrainD showed a female preponderance (11 girls, $69 \%$ ). The largest subgroup (9 patients, 56\%) consisted of patients with anti-NMDA receptor encephalitis and included the youngest patients of all the subgroups. Overall time from symptom onset to diagnosis varied from 6 days to 12 months, with a median duration of 55 days. Patients with the less common conditions, such as anti-GAD65 encephalitis, demonstrated the longest time to diagnosis. Overall, the median follow-up time was 1.7 years (range $0.8-3.7$ years).

Antibody testing. Of the patients diagnosed with antiNMDA receptor encephalitis and anti-GAD65 encephalitis, the majority (9 children, 90\%) had positive antibodies in both serum and CSF. Only 1 child with anti-NMDA receptor encephalitis showed positive antibody testing solely in the CSF. All patients diagnosed with aquaporin-4 (AQP4) autoimmunity showed positive NMO-IgG in the serum, with the exception of one who had repeatedly negative NMO-IgG in serum but a positive test in the CSF. The 2 patients with Hashimoto encephalitis had elevated anti-TPO titers in the serum alongside negative testing of other neuronal autoantibodies.

Anti-NMDA receptor encephalitis. Nine children (6 female, 67\%) were diagnosed with anti-NMDA receptor encephalitis at a median age of 10.8 years (range 3.1-17.9 years). All 9 children presented with encephalopathy and behavioral changes. The latter consisted of severe agitation, irritability, and aggression toward family and medical staff. The majority also showed various movement disorders (dystonic posturing, dyskinesias, and choreatic movements) and seizures. Hallucinations (visual and auditory) were reported in almost half of the patients ( 4 children, 44\%).

Malignancy and systemic inflammatory rheumatologic workups were negative in all patients. MRI studies were also normal in the majority of patients; only 1 child whose initial MRI was performed after 6 days of encephalopathy had abnormal findings consisting of brain edema with effacement of sulci and decreased size of the ventricles (table 2).

ICU admission was required in 4 patients due to uncontrollable agitation ( 2 children), partial status epilepticus ( 1 child), and multiorgan failure (1 child). Immunosuppressive medication was started in all patients; 6 were treated according to the institutional protocol (figures e-1 and e-2) and 3 were treated with a modified immunosuppression regimen without rituximab. All 6 patients presenting with seizures were treated with antiepileptic medication; psychotropic agents were necessary in 7 patients. One child died during the course of the treatment due to acute respiratory distress syndrome and multiorgan failure. At

\begin{tabular}{|c|c|c|c|c|c|c|}
\hline \multirow[t]{2}{*}{ Table 1} & \multicolumn{6}{|c|}{$\begin{array}{l}\text { Demographics, diagnostic delay, acute management, and follow-up of children diagnosed with antibody-associated inflammatory } \\
\text { brain diseases }\end{array}$} \\
\hline & & $\begin{array}{l}\text { Antibody- associated } \\
\text { IBrainD }(n=16)\end{array}$ & $\begin{array}{l}\text { Anti-NMDA receptor } \\
\text { encephalitis }(\mathrm{n}=9)\end{array}$ & $\begin{array}{l}\text { Aquaporin-4 } \\
\text { autoimmunity } \\
(n=4)\end{array}$ & $\begin{array}{l}\text { Hashimoto } \\
\text { encephalitis } \\
(n=2)\end{array}$ & $\begin{array}{l}\text { Anti-GAD65 } \\
\text { encephalitis } \\
(\mathrm{n}=1)\end{array}$ \\
\hline \multicolumn{2}{|c|}{ Females, n (\%) } & $11(69)$ & $6(67)$ & $3(75)$ & $2(100)$ & $0(0)$ \\
\hline \multicolumn{2}{|c|}{ Age at diagnosis, y, median (range) } & $13.3(3.1-17.9)$ & $10.8(3.1-17.9)$ & $16.6(11.8-17.1)$ & $12.1(11.2-12.9)$ & $15.5(-)$ \\
\hline \multicolumn{2}{|c|}{$\begin{array}{l}\text { Time from symptom onset to } \\
\text { diagnosis, } d \text {, median (range) }\end{array}$} & $55(6-358)$ & $47(10-70)$ & $67(13-122)$ & $90(6-173)$ & $358(-)$ \\
\hline \multicolumn{2}{|c|}{$\begin{array}{l}\text { Intensive care unit admission } \\
\text { at onset, } \mathrm{n}(\%)\end{array}$} & $6(38)$ & $4(44)$ & $1(25)$ & $1(50)$ & $0(0)$ \\
\hline \multicolumn{2}{|c|}{$\begin{array}{l}\text { Length of acute management, } \\
\text { d, median (range) }\end{array}$} & $52(5-182)$ & $63(32-182)$ & $35(13-75)$ & $19(5-33)$ & $47(-)$ \\
\hline \multicolumn{2}{|c|}{$\begin{array}{l}\text { Duration of follow-up, y, median } \\
\text { (range) }\end{array}$} & $1.7(0.8-3.7)$ & $1.8(0.8-3.7)$ & $1.5(1.0-1.8)$ & $1.9(1.5-2.2)$ & $2.4(-)$ \\
\hline
\end{tabular}

Abbreviations: IBrainD = inflammatory brain diseases; GAD65 = glutamic acid decarboxylase 65. 


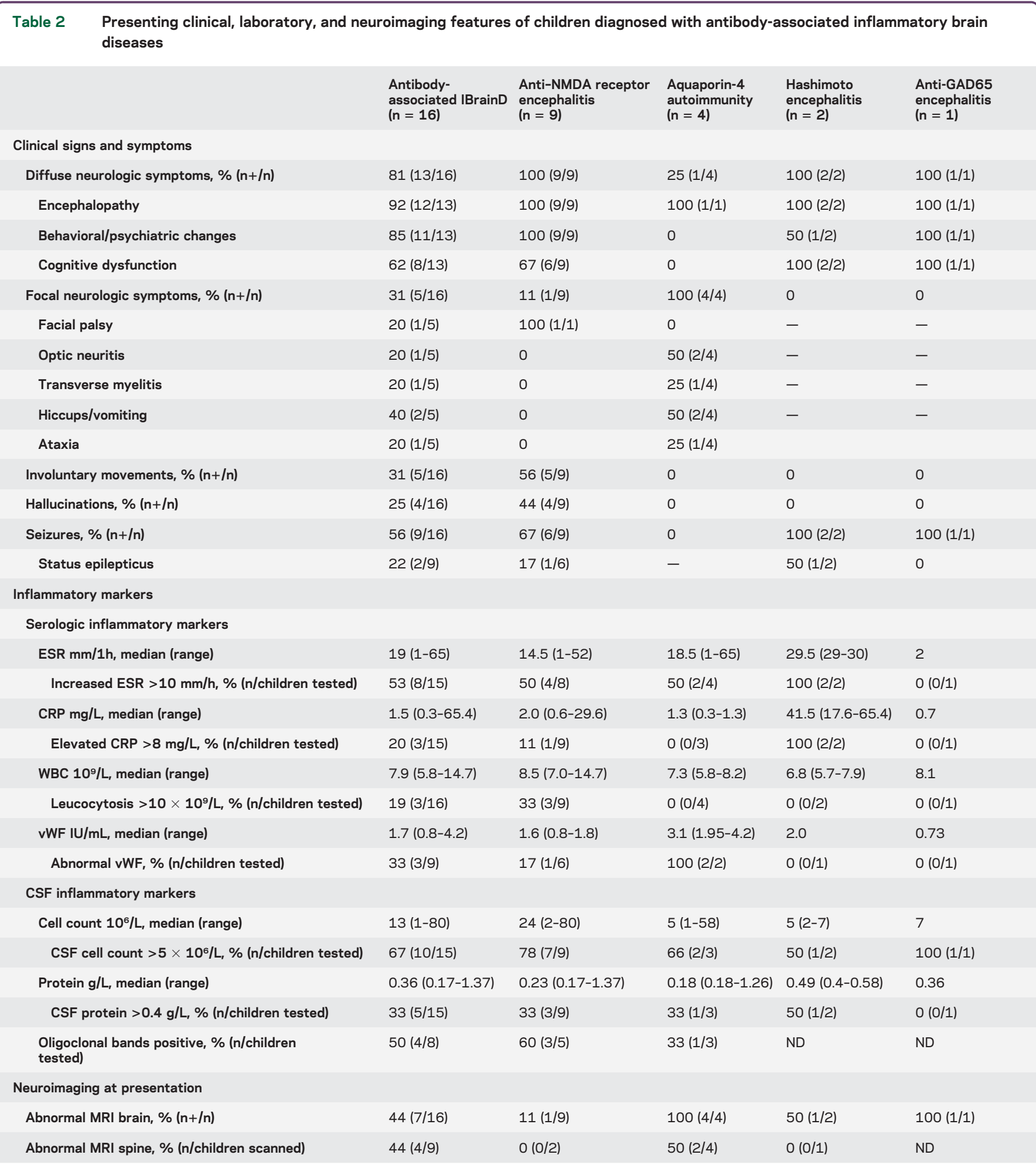

Abbreviations: $\mathrm{CRP}=\mathrm{C}$-reactive protein; $\mathrm{ESR}=$ erythrocyte sedimentation rate; GAD65 = glutamic acid decarboxylase $65 ; \mathrm{IBrainD}=$ inflammatory brain diseases; ND = not done; $\mathrm{VWF}=$ von Willebrand factor; WBC $=$ white blood cell count.

last clinical encounter after a median follow-up time of 1.8 years (range $0.8-3.7$ years), the majority of the surviving children had a good outcome. One child was in a rehabilitation facility due to mild motor and severe behavioral issues. None of the children reported ongoing seizures (table 3).
AQP4 autoimmunity. Four children (3 female, 75\%) were diagnosed with AQP4 autoimmunity at a median age of 16.6 years (range 11.8-17.1 years). All 4 children presented with characteristic focal neurologic signs and symptoms, including intractable hiccups and/or vomiting (2 children), optic neuritis 
Table 3 Outcome of children diagnosed with antibody-associated inflammatory brain diseases at last follow-up

\begin{tabular}{|c|c|c|c|c|c|}
\hline & $\begin{array}{l}\text { Antibody- associated } \\
\text { IBrainD }\end{array}$ & $\begin{array}{l}\text { Anti-NMDA receptor } \\
\text { encephalitis }\end{array}$ & $\begin{array}{l}\text { Aquaporin-4 } \\
\text { autoimmunity }\end{array}$ & $\begin{array}{l}\text { Hashimoto } \\
\text { encephalitis }\end{array}$ & $\begin{array}{l}\text { Anti-GAD65 } \\
\text { encephalitis }\end{array}$ \\
\hline Death, n (\%) & $1(6)$ & $1(11)$ & 0 & 0 & 0 \\
\hline \multicolumn{6}{|l|}{ Neurologic function as defined by PSOM } \\
\hline $\begin{array}{l}\text { Good outcome (no functional neurologic } \\
\text { deficit), } n(\%)\end{array}$ & $11(73)$ & 7 (88) & $3(75)$ & $1(50)$ & 0 \\
\hline $\begin{array}{l}\text { Bad outcome (any functional neurologic } \\
\text { deficit), } n(\%)\end{array}$ & $4(27)$ & $1(12)$ & $1(25)$ & $1(50)$ & 1 \\
\hline \multicolumn{6}{|l|}{ Deficits according to PSOM } \\
\hline Cranial nerve deficits, $n$ & 1 & 0 & 1 & 0 & 0 \\
\hline Motor deficits, $n$ & 0 & 0 & 0 & 0 & 0 \\
\hline Language deficits, $\mathrm{n}$ & 1 & 1 & 0 & 0 & 0 \\
\hline Cognitive/behavior deficits, $n$ & 3 & 1 & 0 & 1 & 1 \\
\hline Residual clinical seizures, $\mathrm{n}(\%)^{\mathrm{b}}$ & $2(22)$ & 0 & N/A & $1(50)$ & 1 \\
\hline On antiepileptic medication, n (\%) & 3 (33) & $1(13)$ & - & $1(50)$ & 1 \\
\hline \multicolumn{6}{|l|}{ Participation } \\
\hline Children attending school, $n$ (\%) & $14(93)$ & $8(100)$ & $4(100)$ & $2(100)$ & 0 \\
\hline IEP or other support required, $n(\%)$ & $5(36)$ & 3 (38) & $1(25)$ & $1(50)$ & - \\
\hline
\end{tabular}

Abbreviations: GAD65 = glutamic acid decarboxylase 65; IBrainD = inflammatory brain diseases; IEP = individualized education program; PSOM = Pediatric Stroke Outcome Measure.

a The child with anti-NMDA receptor encephalitis who died was excluded from further outcome assessment.

${ }^{b}$ Only referring to those 9 patients who presented with seizures at disease onset.

(ON, 1 child), and a diencephalic syndrome with amenorrhea and encephalopathy ( 1 child). One child presented with brainstem symptoms that went undiagnosed over 2 months until the patient developed bilateral ON and LETM. None of the children had seizures or clinical signs suggestive of an underlying systemic autoimmune disease. All 4 patients demonstrated focal lesions on brain MRI. Two children also had spinal cord lesions on presentation; one showed an LETM extending from $\mathrm{C} 2$ to T12/L1 without enhancement and the other had subtle intramedullary signal changes at T3/4 and T8/9 without enhancement (table 2). One child required ICU admission due to clinical deterioration (decreased level of consciousness and inability to secure the airway). Immunosuppressive treatment was started in all patients; the child requiring ICU admission was treated according to the institutional protocol and the remaining 3 were treated with corticosteroids and rituximab only ( 2 children) and azathioprine $100 \mathrm{mg}$ PO daily ( 1 child). At last clinical encounter after a median follow-up time of 1.5 years (range 1.0-1.8 years), 3 patients had a good outcome; the child who presented with ON had a bad outcome according to the PSOM, remaining blind in one eye (table 3 ).

Hashimoto encephalitis. Two previously normally developed female patients, ages 13 and 11 years, presented with decline in school performance, progressive encephalopathy over a few weeks, and seizures.
Neither patient presented with focal neurologic deficits. Serologic inflammatory markers were mildly elevated (table 2). Inflammatory rheumatologic workup revealed positive anti-TPO titers of $376 \mathrm{IU} / \mathrm{L}(<35)$ and 6,747 IU/L $(<35)$, respectively, alongside normal thyroid function (thyroid-stimulating hormone, T3, and T4). The latter child had been diagnosed with Hashimoto thyroiditis the year before and was being treated with levothyroxine $50 \mu \mathrm{g} / \mathrm{day}$. CSF inflammatory markers and an extensive infectious and metabolic workup were noncontributory. Brain MRI was abnormal in 1 child, showing symmetric high fluid-attenuated inversion recovery (FLAIR) and T2 signal with mild enlargement of bilateral amygdala and hippocampi. The lesions were neither enhancing nor diffusion-restricted. The 11-year-old girl required ICU admission due to status epilepticus. Her initial EEG showed periodic lateralized epileptiform discharges (left $>$ right), electroencephalographic seizures, and diffuse slowing. The EEG of the 13-year-old girl showed intermittent left frontal and midline frontal slowing with no epileptiform discharges, and she had a normal brain MRI (table 2). She recovered spontaneously after 5 days of hospital admission and did not require further treatment.

The patient in the ICU continued to be encephalopathic despite control of seizure activity with double antiepileptic medication. She was started on the institutional immunosuppressive protocol and discharged 
into a rehabilitation facility where she continued to improve slowly. After a follow-up time of 2.2 years, she had a normalized anti-TPO titer and an absence of focal neurologic deficits but continued to have seizures several times a month. As a result, she also experienced marked cognitive sequelae that required a modified educational curriculum (table 3). Her last brain MRI, performed 2 years after disease onset, revealed bilateral hippocampal volume loss.

Anti-GAD65 encephalitis. A 15-year-old previously healthy boy presented with a self-limited $(<5$ minutes $)$ generalized tonic-clonic seizure. $\mathrm{He}$ reported 8-9 months of moderately severe nonthrobbing headaches occurring several times per week, 1 month of amnestic events, and 1 week of leg twitching occurring 2-3 times/day. No focal neurologic deficits were noted on examination. Laboratory investigations, including complete blood count, CRP, ESR, electrolytes, kidney and liver function tests, thyroid function anti-TPO antibodies, and anti-NMDA receptor antibodies, were normal. CSF analysis was remarkable for 7 white blood cells, normal glucose, and normal protein (table 2). CSF cytopathology and encephalitis workup was unremarkable. EEG demonstrated asymmetrical slowing of the background rhythm in the left hemisphere with epileptiform activity. Brain MRI revealed abnormal high T2 and FLAIR signal in the right hippocampus associated with mild swelling and bilateral signal abnormality in the amygdalae without enhancement. The patient was started on levetiracetam $500 \mathrm{mg}$ BID and discharged after no further seizures occurred. Three months later, he presented with an increased frequency of focal seizures (one seizure every 3 hours). Seizure semiology was significant for nonsuppressible left leg twitching. Daily episodes of confusion lasting 30-60 minutes, a decline in school performance, a subjective sensation of "mental fog," and decreased memory function were also reported. On readmission, no psychiatric disturbances, focal neurologic deficits, or dyskinesia were noted on examination. Montreal Cognitive Assessment score was normal (30/30); however; he demonstrated significant difficulties in recalling events that occurred earlier the same day. Brain MRI was unchanged compared to prior studies. Twenty-four-hour EEG recording captured a total of 6 ictal episodes ( 3 originating from the right hemisphere and 3 from the left hemisphere). Repeat CSF analysis demonstrated 9 white blood cells, normal glucose and protein, and positive oligoclonal banding. The combination of EEG and neuroimaging findings prompted the diagnosis of limbic encephalitis. Levetiracetam was increased to 1,500 mg BID. Further analyses of antineuronal (intracellular and extracellular) antibodies demonstrated the presence of anti-GAD65 antibodies in both serum and CSF. The patient was started on the institutional treatment protocol for $\mathrm{AB}$-associated IBrainD (see figures e-1 and e-2). At last follow-up, 2.4 years after diagnosis, the patient was still having focal seizures several times per week. At that time, he was unable to attend school and reported significant memory loss and moodiness (table 3). The last brain MRI, performed approximately 2 years after diagnosis, showed right hippocampal volume loss with mild T2 and FLAIR hyperintensity in both amygdalae.

DISCUSSION In this study, we systematically described the clinical spectrum of $\mathrm{AB}$-associated IBrainD in children. AB-associated IBrainD comprise approximately $10 \%$ of all pediatric IBrainD. The spectrum of $\mathrm{AB}$-associated $\mathrm{IBrainD}$ is rapidly evolving due to an increasing ability to detect autoantibodies (figure 2). Children present with a wide range of symptoms, including encephalopathy, seizures, involuntary movements, and various focal neurologic deficits. The clinical heterogeneity has a significant impact on the time to diagnosis, which was approximately 2 months in our study. AB-associated IBrainD have devastating consequences for patients and families, as they led to function-limiting neurologic sequelae in one-fourth of our study population. Delays in diagnosis have been shown to be associated with further adverse outcomes. ${ }^{13-15}$ However, specific antibody testing and targeted treatment approaches are now available. As a result, it is of clinical importance to increase the awareness of the distinct pediatric $\mathrm{AB}$-associated $\mathrm{IBrainD}$ phenotypes in order to shorten the time from symptom onset to diagnosis and to ensure timely initiation of treatment.

The clinical spectrum of AB-associated IBrainD is heterogeneous. The study revealed a dichotomous division of the 2 major clinical phenotypes: the first, comprised of encephalopathy and seizures, is often seen alongside an unremarkable MRI and/or an MRI with lesions secondary to prolonged seizure activity, and the second involves focal neurologic deficits accompanied by a characteristically abnormal MRI. In this study, anti-NMDA receptor encephalitis, anti-GAD65 encephalitis, and Hashimoto encephalopathy belonged to the first category, whereas AQP4 autoimmunity belonged to the second. Considering the pathophysiologic mechanisms of the antibodies, this seems biologically plausible for both anti-NMDA receptor encephalitis and antiGAD65 encephalitis, whereas the pathophysiologic mechanism involved in Hashimoto encephalopathy remains unknown. Anti-NMDA receptor antibodies lead to internalization and a subsequent reduction in the number of NMDA receptors on the cell surface. This ultimately results in a characteristic clinical phenotype that includes behavioral, learning, and 


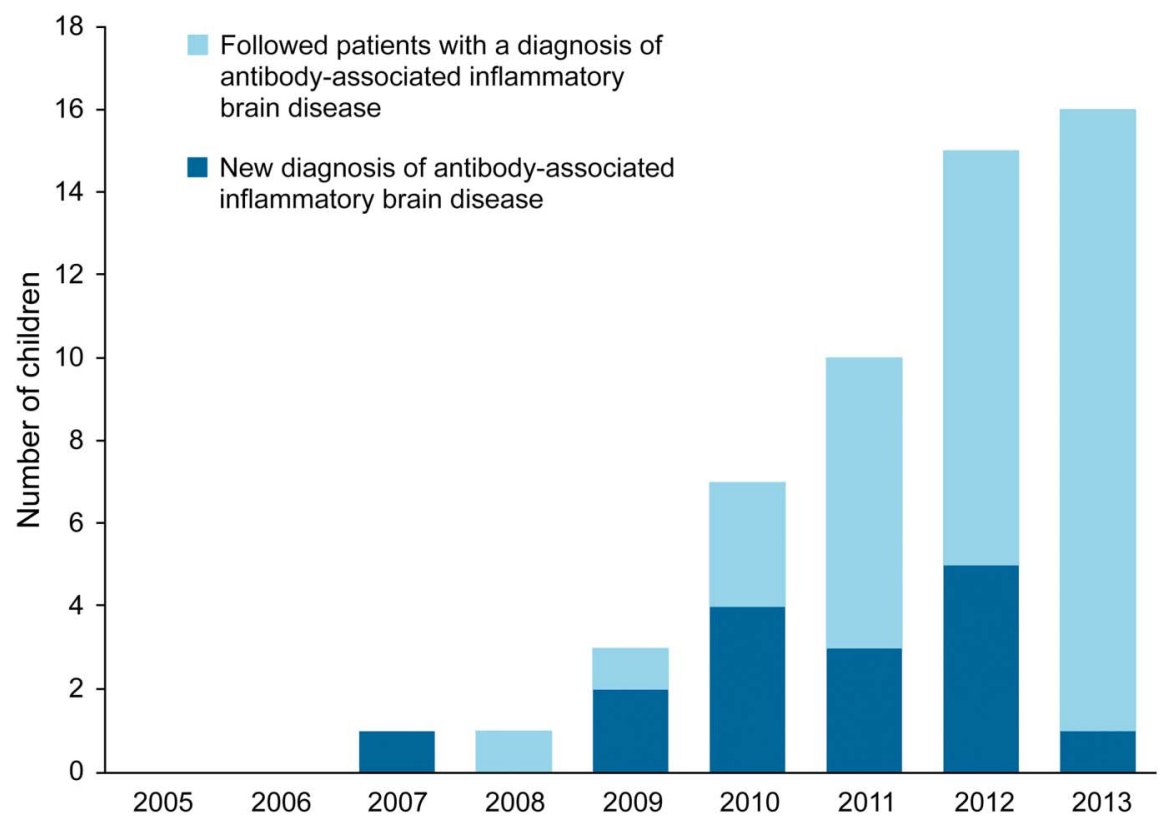

memory dysfunction as well as encephalopathy and seizures, all in the context of a seemingly normal MRI or an MRI with changes attributed to prolonged seizure activity only. ${ }^{16-18}$ Similarly, in anti-GAD65 encephalitis, the antibody is thought to interfere with GABA metabolism, leading to increased seizure activity. ${ }^{19-21}$ However, while the pathogenetic mechanism in anti-NMDA receptor encephalitis has been wellestablished, the role of the anti-GAD65 antibody is not fully understood yet. In contrast, the NMO-IgG binds to the AQP4 channel on the foot processes of astrocytes, leading to an acute and often destructive inflammatory process that can be seen on MRI in AQP4-dense areas of the brain, such as the area postrema or the diencephalon. ${ }^{9,22-26}$ This explains the clinical presentation of pediatric patients with AQP4 autoimmunity. Upon presentation, they frequently show symptoms other than $\mathrm{ON}$ or transverse myelitis but with a clear localization to AQP4 dense areas. These symptoms have been previously described and include intractable hiccups/vomiting, encephalopathy, endocrinopathies, and menstrual irregularities. $^{2,27,28}$ Hence, AB-associated IBrainD remain an important differential diagnosis not only among IBrainD but also within the broader field of pediatric neurology.

Unique to AB-associated IBrainD is the availability of a biomarker that is the antibody itself. Serologic and CSF inflammatory markers are rather unspecific; however, antibody testing facilitates a specific diagnosis. In contrast, other IBrainD lack specific biomarkers and rely heavily on invasive tests. For example, in patients with suspected CNS vasculitis, conventional angiography (large vessel vasculitis) or even brain biopsy (small vessel vasculitis) is required to establish the diagnosis. ${ }^{29-34}$

Rapid, comprehensive testing using serum and CSF is needed to avoid delays in diagnosis. Overall, CSF testing appears to be more sensitive and specific. Two patients (12.5\%) - 1 with anti-NMDA receptor encephalitis and 1 with AQP4 autoimmunityhad positive antibody testing in CSF only, while the sera remained negative. A recent study analyzing 250 patients with anti-NMDA receptor encephalitis demonstrated that CSF antibody testing had a higher sensitivity than serum antibody testing $(100 \%$ vs $85.6 \%, p<0.0001) .{ }^{35}$ Other authors have also indicated that serum has a lower sensitivity and specificity than CSF for NMDA receptor antibody determination; in addition, the disorder is characterized by intrathecal antibody synthesis. ${ }^{11,36,37}$ Therefore, in patients with anti-NMDA receptor encephalitis, antibody testing in serum alone carries the risk of missing or delaying the diagnosis in a potentially devastating but treatable neurologic disease. In contrast, in patients with AQP4 autoimmunity, the role of CSF antibody testing remains controversial, and intrathecal synthesis of AQP4 antibody is questionable. ${ }^{38-41}$ However, our study and the literature report AQP4 antibody in CSF in seronegative patients. Since early and targeted treatment initiation is key in preventing relapses and permanent disability, CSF AQP4 antibody testing may need to be considered in patients with a high clinical suspicion of AQP4 autoimmunity despite seronegativity. It is also important to consider the type of assay used. Although there is a high 
specificity for AQP4 antibody among various immunologic techniques, cell-based assays seem to be more sensitive than tissue- or protein-based assays. ${ }^{42}$

The limitations of this study are inherent to its retrospective design. First, selection bias should be noted, given that The Hospital for Sick Children is a tertiary care center that receives referrals for sicker patients. Second, since recognition of antibodyassociated conditions is growing, an underestimation of the number of $\mathrm{AB}$-associated $\mathrm{IBrainD}$ earlier in the study period is likely. Finally, the small size of the Hashimoto encephalitis and anti-GAD65 encephalitis groups does not guarantee external validity.

An increasing number of children have been diagnosed with AB-associated IBrainD over the past decade. One-fourth of our patients were left with function-limiting sequelae. The devastating potential of these conditions underscores the need for increased awareness and understanding of their clinical presentation. This in turn will facilitate faster comprehensive antibody testing, ultimately leading to more timely treatment for children. As shown in our study, antibody-associated diseases are an evolving spectrum. More advanced immunohistochemical techniques are likely to discover more antibodies involved in the pathogenesis of neurologic conditions currently considered of "unknown origin." Beyond the antibody-associated diseases presented in this study, antibodies may also play a role in the symptom evolution of neurologic diseases otherwise considered static. It is possible that a lesion might function as a trigger for an antibody-mediated or antibodyassociated inflammatory reaction, conceptually leading to secondary $\mathrm{AB}$-associated IBrainD. Therefore, larger multicenter prospective studies are required in order to better understand the heterogeneous nature of $\mathrm{AB}$-associated IBrainD and to compare different immunosuppressive treatment strategies.

\section{AUTHOR CONTRIBUTIONS}

All authors contributed to the design and conduct of the study, had access to all data in the study, and hold final responsibility for the decision to submit this manuscript for publication.

\section{ACKNOWLEDGMENT}

The authors thank research assistants Shehla Sheikh and Anastasia Dropol for their help and support during the data collection.

\section{STUDY FUNDING}

Supported in part by the National Institute of Health (NIH, RO1NS077851, J.D.) and Fondo de Investigaciones Sanitarias (FIS, 11/01780, J.D.).

\section{DISCLOSURE}

S. Bigi received research support from Swiss National Science Foundation and Anna Muller Grocholski Foundation. M. Hladio received research support from Canadian Rheumatology Association. M. Twilt reports no disclosures. J. Dalmau is editor of Neurology: Neuroimmunology \& Neuroinflammation; is on the editorial board for Neurology UpToDate; holds patents for and received royalties from Ma2 autoantibody test, NMDA receptor autoantibody test, GABA(B) receptor autoantibody test, GABA(A) receptor autoantibody test, DPPX autoantibody test, and IgLON5 autoantibody test; and received research support from Euroimmun, NIH, and Fondo de Investigaciones Sanitarias de la Seguridad Social, ISCIII (Spanish Government). S.M. Benseler reports no disclosures. Go to Neurology.org/nn for full disclosure forms.

Received October 15, 2014. Accepted in final form January 26, 2015.

\section{REFERENCES}

1. Twilt M, Benseler SM. The spectrum of CNS vasculitis in children and adults. Nat Rev Rheumatol 2012;8:97-107.

2. Tillema JM, McKeon A. The spectrum of neuromyelitis optica (NMO) in childhood. J Child Neurol 2012;27: 1437-1447.

3. Lancaster E, Martinez-Hernandez E, Dalmau J. Encephalitis and antibodies to synaptic and neuronal cell surface proteins. Neurology 2011;77:179-189.

4. Armangue T, Titulaer MJ, Málaga I, et al. Pediatric anti$\mathrm{N}$-methyl-D-aspartate receptor encephalitis-clinical analysis and novel findings in a series of 20 patients. J Pediatr 2013;162:850.e2-856.e2.

5. Banwell B, Tenembaum S, Lennon VA, et al. Neuromyelitis optica-IgG in childhood inflammatory demyelinating CNS disorders. Neurology 2008;70:344-352.

6. Dalmau J, Tuzun E, Wu HY, et al. Paraneoplastic anti-Nmethyl-D-aspartate receptor encephalitis associated with ovarian teratoma. Ann Neurol 2007;61:25-36.

7. Lennon VA, Wingerchuk DM, Kryzer TJ, et al. A serum autoantibody marker of neuromyelitis optica: distinction from multiple sclerosis. Lancet 2004;364:2106-2112.

8. Weinshenker BG, Wingerchuk DM, Pittock SJ, Lucchinetti CF, Lennon VA. NMO-IgG: a specific biomarker for neuromyelitis optica. Dis Markers 2006;22: 197-206.

9. Pittock SJ, Weinshenker BG, Lucchinetti CF, Wingerchuk DM, Corboy JR, Lennon VA. Neuromyelitis optica brain lesions localized at sites of high aquaporin 4 expression. Arch Neurol 2006;63:964-968.

10. Hernán Martínez J, Torres O, Mangual MM, et al. Hashimoto's encephalopathy: an underdiagnosed clinical entity. Bol Asoc Med P R 2013;105:57-61.

11. Dalmau J, Gleichman AJ, Hughes EG, et al. AntiNMDA-receptor encephalitis: case series and analysis of the effects of antibodies. Lancet Neurol 2008;7:10911098.

12. deVeber GA, MacGregor D, Curtis R, Mayank S. Neurologic outcome in survivors of childhood arterial ischemic stroke and sinovenous thrombosis. J Child Neurol 2000; 15:316-324.

13. DeSena AD, Greenberg BM, Graves D. Three phenotypes of anti-N-methyl-D-aspartate receptor antibody encephalitis in children: prevalence of symptoms and prognosis. Pediatr Neurol 2014;51:542-549.

14. Kim SH, Kim W, Li XF, Jung IJ, Kim HJ. Clinical spectrum of CNS aquaporin-4 autoimmunity. Neurology 2012;78:1179-1185.

15. Markakis I, Alexopoulos H, Poulopoulou C, et al. Immunotherapy-responsive limbic encephalitis with antibodies to glutamic acid decarboxylase. J Neurol Sci 2014;343:192-194.

16. Manto M, Dalmau J, Didelot A, Rogemond V, Honnorat J. In vivo effects of antibodies from patients with anti-NMDA receptor encephalitis: further evidence 
of synaptic glutamatergic dysfunction. Orphanet J Rare Dis 2010;5:31.

17. Hughes EG, Peng X, Gleichman AJ, et al. Cellular and synaptic mechanisms of anti-NMDA receptor encephalitis. J Neurosci 2010;30:5866-5875.

18. Moscato EH, Jain A, Peng X, Hughes EG, Dalmau J, Balice-Gordon RJ. Mechanisms underlying autoimmune synaptic encephalitis leading to disorders of memory, behavior and cognition: insights from molecular, cellular and synaptic studies. Eur J Neurosci 2010;32:298-309.

19. Mishra N, Rodan LH, Nita DA, Gresa-Arribas N, Kobayashi J, Benseler SM. Anti-glutamic Acid decarboxylase antibody associated limbic encephalitis in a child: expanding the spectrum of pediatric inflammatory brain diseases. J Child Neurol 2014;29:677-683.

20. Dinkel K, Meinck HM, Jury KM, Karges W, Richter W. Inhibition of gamma-aminobutyric acid synthesis by glutamic acid decarboxylase autoantibodies in stiff-man syndrome. Ann Neurol 1998;44:194-201.

21. Kanter IC, Huttner HB, Staykov D, et al. Cyclophosphamide for anti-GAD antibody-positive refractory status epilepticus. Epilepsia 2008;49:914-920.

22. Pittock SJ, Lennon VA, Krecke K, Wingerchuk DM, Lucchinetti CF, Weinshenker BG. Brain abnormalities in neuromyelitis optica. Arch Neurol 2006;63:390-396.

23. Misu T, Takano R, Fujihara K, Takahashi T, Sato S, Itoyama Y. Marked increase in cerebrospinal fluid glial fibrillar acidic protein in neuromyelitis optica: an astrocytic damage marker. J Neurol Neurosurg Psychiatry 2009;80:575-577.

24. Takano R, Misu T, Takahashi T, Sato S, Fujihara K, Itoyama Y. Astrocytic damage is far more severe than demyelination in NMO: a clinical CSF biomarker study. Neurology 2010;75:208-216.

25. Lucchinetti CF, Guo Y, Popescu BF, Fujihara K, Itoyama $\mathrm{Y}$, Misu T. The pathology of an autoimmune astrocytopathy: lessons learned from neuromyelitis optica. Brain Pathol 2014;24:83-97.

26. Popescu BF, Lennon VA, Parisi JE, et al. Neuromyelitis optica unique area postrema lesions: nausea, vomiting, and pathogenic implications. Neurology 2011;76:1229-1237.

27. Lotze TE, Northrop JL, Hutton GJ, Ross B, Schiffman JS, Hunter JV. Spectrum of pediatric neuromyelitis optica. Pediatrics 2008;122:e1039-e1047.

28. Huppke P, Bluthner M, Bauer O, et al. Neuromyelitis optica and NMO-IgG in European pediatric patients. Neurology 2010;75:1740-1744.

29. Benseler SM, Silverman E, Aviv RI, et al. Primary central nervous system vasculitis in children. Arthritis Rheum 2006;54:1291-1297.
30. Cellucci T, Benseler SM. Diagnosing central nervous system vasculitis in children. Curr Opin Pediatr 2010;22: 731-738.

31. Cellucci T, Tyrrell PN, Twilt M, Sheikh S, Benseler SM. Distinct phenotype clusters in childhood inflammatory brain diseases: implications for diagnostic evaluation. Arthritis Rheumatol 2014;66:750-756.

32. Elbers J, Halliday W, Hawkins C, Hutchinson C, Benseler SM. Brain biopsy in children with primary small-vessel central nervous system vasculitis. Ann Neurol 2010;68:602-610.

33. Benseler SM, deVeber G, Hawkins C, et al. Angiographynegative primary central nervous system vasculitis in children: a newly recognized inflammatory central nervous system disease. Arthritis Rheum 2005;52: 2159-2167.

34. Aviv RI, Benseler SM, Silverman ED, et al. MR imaging and angiography of primary CNS vasculitis of childhood. AJNR Am J Neuroradiol 2006;27:192-199.

35. Gresa-Arribas N, Titulaer MJ, Torrents A, et al. Antibody titres at diagnosis and during follow-up of anti-NMDA receptor encephalitis: a retrospective study. Lancet Neurol 2014; 13:167-177.

36. Irani SR, Bera K, Waters $\mathrm{P}$, et al. N-methyl-D-aspartate antibody encephalitis: temporal progression of clinical and paraclinical observations in a predominantly nonparaneoplastic disorder of both sexes. Brain 2010;133: $1655-1667$.

37. Viaccoz A, Desestret V, Ducray F, et al. Clinical specificities of adult male patients with NMDA receptor antibodies encephalitis. Neurology 2014;82:556-563.

38. Klawiter EC, Alvarez E III, Xu J, et al. NMO-IgG detected in CSF in seronegative neuromyelitis optica. Neurology 2009;72:1101-1103.

39. Jarius S, Franciotta D, Paul F, et al. Cerebrospinal fluid antibodies to aquaporin- 4 in neuromyelitis optica and related disorders: frequency, origin, and diagnostic relevance. J Neuroinflammation 2010;7:52.

40. Bennett JL, Lam C, Kalluri SR, et al. Intrathecal pathogenic anti-aquaporin- 4 antibodies in early neuromyelitis optica. Ann Neurol 2009;66:617-629.

41. Kalluri SR, Illes Z, Srivastava R, et al. Quantification and functional characterization of antibodies to native aquaporin 4 in neuromyelitis optica. Arch Neurol 2010;67: 1201-1208.

42. Jarius S, Wildemann B. Aquaporin-4 antibodies (NMO$\operatorname{IgG})$ as a serological marker of neuromyelitis optica: a critical review of the literature. Brain Pathol 2013;23: 661-683. 


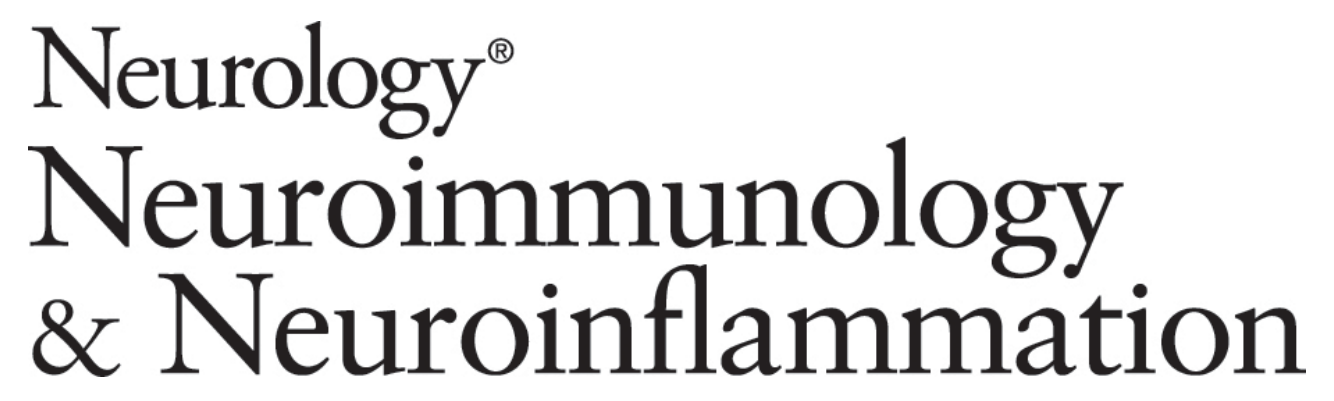

The growing spectrum of antibody-associated inflammatory brain diseases in children Sandra Bigi, Manisha Hladio, Marinka Twilt, et al.

Neurol Neuroimmunol Neuroinflamm 2015;2;

DOI 10.1212/NXI.0000000000000092

This information is current as of April 2, 2015

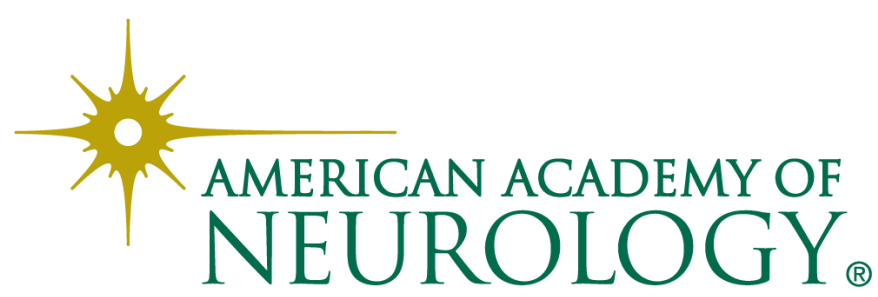




\section{Updated Information \& Services}

\section{Supplementary Material}

\section{References}

Citations

Subspecialty Collections

Permissions \& Licensing

Reprints including high resolution figures, can be found at: http://nn.neurology.org/content/2/3/e92.full.html

Supplementary material can be found at: http://nn.neurology.org/content/suppl/2015/04/02/2.3.e92.DC1

This article cites 42 articles, 2 of which you can access for free at: http://nn.neurology.org/content/2/3/e92.full.html\#\#ref-list-1

This article has been cited by 2 HighWire-hosted articles: http://nn.neurology.org/content/2/3/e92.full.html\#\#otherarticles

This article, along with others on similar topics, appears in the following collection(s):

All Neuropsychology/Behavior

http://nn.neurology.org//cgi/collection/all_neuropsychology_behavior All Pediatric

http://nn.neurology.org//cgi/collection/all_pediatric

Autoimmune diseases

http://nn.neurology.org//cgi/collection/autoimmune_diseases Devic's syndrome

http://nn.neurology.org//cgi/collection/devics_syndrome

\section{Hallucinations}

http://nn.neurology.org//cgi/collection/hallucinations

Information about reproducing this article in parts (figures,tables) or in its entirety can be found online at:

http://nn.neurology.org/misc/about.xhtml\#permissions

Information about ordering reprints can be found online:

http://nn.neurology.org/misc/addir.xhtml\#reprintsus

Neurol Neuroimmunol Neuroinflamm is an official journal of the American Academy of Neurology.

Published since April 2014, it is an open-access, online-only, continuous publication journal. Copyright $\odot$ 2015 American Academy of Neurology. All rights reserved. Online ISSN: 2332-7812.

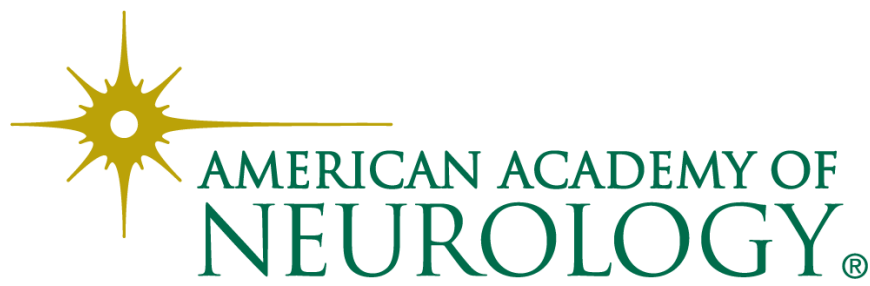

